\title{
A Network Analysis Approach to the Diffusion of Tolerance Memes Amira S. N. Tawadros
}

Department of Socio-Computing

Faculty of Economics and Political Science, Cairo University

\begin{abstract}
The world is now in an age where the electronic media has drawn people from different cultures closer together into what is called a "Global Society". The flow of ideas, thoughts, and values has become much easier and more rabid than before. Tolerant ideas and values as well as hatred and violent thoughts can propagate easier in this new global society. While violent and terrorist ideas propagate quickly (as in case of ISIS), tolerant ideas and practices may fail to reach their target population efficiently due to the lack of an explicit diffusion strategy and/or the lack of an implementation strategy that acknowledge the social structure that binds together the members of the targeted community. The article assumes that we can create the basis for the emergence of a social context where tolerance values can be diffused by targeting social networks not social classes, age, religious groups, or institutions. This article outlines how social network analysis can be effective as: 1) a new framework of analysis that is more relevant for understanding, describing and dealing with community dynamics, 2) a tool for diffusing tolerant ideas (memes) within a targeted community, and 3) an identifier of the influential actors in the target community in order to optimize the diffusion of tolerant memes.
\end{abstract}

Keywords: Network Analysis, Memetics, Toleration, Diffusion 
مجلة وادي النيل للاراسات والبحوث الإنسانية و الاجتماعية والتربوية (مجلة علمية محكمة)

(ISSN : 2536 - 9555)

\section{Introduction}

The world in which we live today suffers a lot from the wide spread of hatred speech, intolerant ideas, and violent actions towards the "different" other. Moreover, with the advances that the last century witnessed in Information and Communication Technology (ICT), and the introduction of the World Wide Web (Internet), Intolerant and violent ideas propagate much more easily and quickly than ever. Worldwide networks of terror emerged, recruiting daily hundreds of youth from different cultures and nationalities. On the other hand, separate voices raised in favor of tolerance towards other, coexistence and peace-building still fail to reach their target population.

This article aims at developing an analytical framework characterizing the Memetic Diffusion of tolerant ideas through Social Networks as a function of its structural properties. The article starts with clarifying the main concepts of memes, memetic diffusion, and social networks. Then, the effect of some structural (network) characteristics on the diffusion of tolerant memes will be discussed in more detail.

\section{Models of Community Dynamics}

How people adopt ideas as well as social behaviors from one another in a collective environment is one of the basic enquiries regarding human dynamics in a society. Several models were built in this field, some of which (the relevant ones) will be discussed in the following paragraphs.

\subsection{The Threshold Model}

Threshold model describes how people decide to adopt ideas or behaviors stating that people tend to follow the same trend as most of their friends do so (Granovetter, 1978; Morris, 2000).

A threshold is defined as the number or proportion of others who must adopt an idea before a given individual adopts it. Considering 
A Network Analysis Approach to the Diffusion of Tolerance Memes Amira S. N. Tawadros

مجلة وادي النيل للاراسات والبحوث الإنسانية والاجتماعية والتربوية (مجلة علمية محكمة)

that influences of friends, neighbors, or family on a given individual vary according to their relationship to this person, therefore the threshold value varies as well.

The Homophily Principle suggests that similar people are more likely to have contact than dissimilar ones, "similarity breeds connection". A feedback loop (or the Echo-Chamber Effect) was claimed to result in similarity among users (Weng, 2014). An individual $\mathrm{X}$ imitate another individual $\mathrm{Y}$ because they are similar in some way, and meanwhile they are becoming more and more similar.

\subsection{Epidemic Models and Memetic Diffusion}

Inspired by epidemic spreading techniques in medical studies, early models concerning communication dynamics in human societies were built (Rapoport, 1953).

These models assume that ideas, information and knowledge are transmitted among people in each society through social connections the same way infectious disease is transmitted among population through infection (Tawadros, 2012).

A Meme, as introduced by Richard Dawkins (1989), refers to an idea or a piece of information that can be shared and transmitted from one person to another. Based on this definition a meme can be considered as a unit of cultural transmission, or a unit of imitation.

Memes, that leap flea-wise from head to head, could be seen as the cultural analogs of viruses that are transmitted through the communications of individuals (Alvarez, 2004).

Examples of memes include words, phrases, pieces of music, tag, or URLs on the internet, all of which are transmissible among online users and replicated on the social media platforms. A widely adopted example is using Twitter hashtag as a meme indicator. 
مجلة وادي النيل للاراسات والبحوث الإنسانية والاجتماعية والتربوية (مجلة علمية محكمة)

(ISSN : 2536 - 9555)

Memetic Diffusion is viewed as a process that resembles the spread of an infectious disease. The carrier of a certain meme directly or indirectly communicates this meme to another person, who now also becomes a carrier, ready to 'infect' further people, and so on (Heylighen \& Chielens, 2008).

Although numerous memes are created everyday only few of them go viral. A truly successful or viral meme is one that spreads like an epidemic, infecting a huge portion of the population.

Several models in literature studied memetic diffusion, e.g. Dawkins (1989); Henson (1990); Heylighen (1992), (1997) and (1998); Hales (1996); Chielens and Heylighen (2005) ${ }^{1}$. These studies focused mainly on the criteria upon which a specific meme is more successful in infecting recipient's mind, or in other words propagating more widely, than other memes.

Moreover, The SIS (Bailey, 1975) and SIR (Anderson \& May, 1991) are two classical models in epidemiology that divided the population into two categories, either Susceptible (S) or Infected (I) with the meme. Later, a probability of Recovery (R) from infection was introduced. The main focus here is on how memes are transmitted from individual to individual.

However, none of the pre-discussed studies or models took into consideration the underlying social network structure of how individuals are connected.

\section{Social Network Analysis (SNA) as a Distinct Framework for studying Community Dynamics}

The concept of a social network and its methods of analysis have attracted considerable interest from scholars in social and behavioral sciences in recent decades. Much of this interest can be attributed to the appealing focus of social network analysis on relationships among social entities, and on the patterns and

${ }^{1}$ For a detailed review refer to Tawadros (2012).

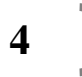


A Network Analysis Approach to the Diffusion of Tolerance Memes Amira S. N. Tawadros

مجلة وادي النيل للاراسات والبحوث الإنسانية والاجتماعية والتربوية (مجلة علمية محكمة)

implications of these relationships. The social environment can be expressed as patterns or regularities in relationships among interacting units. Hence, Structure refers to the regular patterns in relationships, and Structural variables refer to quantitative measures of this structure (Wasserman and Faust, 1994).

Social Network Analysis (SNA) is a distinct framework for studying community dynamics because it is based on assuming the importance of relationships among interacting units. This perspective encompasses theories, models, and applications that are expressed in terms of relational concepts or processes.

SNA can also be considered as an empirical tool which can be used to visualize, identify, measure and analyze the ties between people, groups, and organizations (Scott, 1991). In doing so, it uncovers the often-invisible patterns of interaction and enables the underlying structure of relationships to become visible (Cross et. al., 2002).

There is an extensive evidence in literature that the structure of networks, in terms of both the pattern of connections as well as the way in which individuals are distributed across them, alters aggregate outcomes (Siegel, 2009).

The earliest roots of SNA can be traced to social psychology at the turn of the $20^{\text {th }}$ century, but particularly what Jacob Moreno and Helen Jennings referred to as sociometry in the 1930s (Moreno \& Jennings, 1938). However, contemporary social network analysis received a huge focus in the 1970s with the work of Harrison White and his students (Rice \& Yoshioka-Maxwell, 2015).

Moreover, since the development of systems ideas (Katz \& Kahn, 1966 and Thompson, 1967), organization theorists have focused on the interaction between social objects (actors) in an organization in producing behavior. Network analysis is one method of conceptualizing systems that captures the intersection of both static and dynamic aspects by focusing on the linkages between social objects over time. Tichy, et. al (1979), for instance, studied the capability of SNA in linking the micro and macro approaches to 
organizational behavior, addressing organization from a System perspective, i.e., a set of objects (e.g. people or groups) joined by a variety of relationships.

SNA has had extensive use in the analysis of organized crime groups and terrorism as well. Since the 1930s, researchers have identified the significance of network structures in facilitating criminal interactions (Lauchs, et. al., 2012). They used SNA as a method to analyze organized crime (e.g., Sutherland, 1937; Block, 1994; McIllwain, 1999; Bruinsma and Bernasco, 2004; Kleemans and de Poot, 2008; and Heber, 2009). Within an organized crime network, SNA techniques can identify network members that control information flow within the criminal network and how the removal of one or more members can inhibit the flow of information or alter the network's ability to adapt or perform at its best (Carley et al., 2002).

Moreover, SNA were also used to study the dynamics of social movements, collective action, opinion dynamics and consensus decision making. Snow, Zurcher, and Ekland-Olson (1980) studied the differential recruitment and propagation of social movements, addressing questions like: Why are some people rather than others recruited into a particular social movement organization? Why do some movement organizations attract a larger following and grow at a more rapid rate than others?

Similarly, Siegel (2009) studied the effect of structural variables and relationships among individuals on the emergence of "Collective Action", addressing questions like: How would the political outcome have been different had the network been different? How much weaker would the incentive to engage in violence have been for members of the global Salafi Jihad had existing cliques been weaker?

More recently, Kleinnijenhuis et al. (2011) used a network analysis of organizational communication in order to study Social Influence in Networks of Practice (NoP) addressing issues like: social identity theory, persuasion and attitude change, minority influence, group influence, etc. 
A Network Analysis Approach to the Diffusion of Tolerance Memes Amira S. N. Tawadros

مجلة وادي النيل للاراسات والبحوث الإنسانية والاجتماعية والتربوية (مجلة علمية محكمة)

Many scholars as well used SNA to study the impact of network structure on the diffusion of innovations as well. The history of network models of diffusion (Liu, Madhavan, and Sudharshan, 2005):

- Opinion leadership (Coleman et al., 1966)

- Strength of weak ties (Granovetter, 1973)

- Communication network (Rogers and Kincaid, 1981)

- Structural equivalence (Burt, 1987)

For more insights about the history of SNA, refer to Freeman (2004) - The development of Social Network Analysis: A Study in the Sociology of Science.

Following the line of research in using SNA techniques in studying human dynamics, one can conclude the following points:

1. Based on social movement literature, one could conclude that the network channel is the richest source of movement recruits. Network linkages are proved to be crucial for recruitment in religious, political and social movements. Hence, SNA is very important as a conduit for the spread of social movements.

2. Better in-depth understanding of the importance of network structure in participation in collective actions will help scholars in this field as well to understand the determinants of aggregate outcomes or behaviors.

3. The structure of networks among individuals (actors) in a specific community significantly alters the aggregate behavior in this community. Structure here refers to both; the pattern of connections (ties) and the way in which individuals are distributed (positions).

4. SNA is a useful approach in understanding complex systems, and how micro-behaviors and dynamics can produce the emergence of macro-phenomena. According to Mitchell's (1969) view, a specific set of lies or linkages among any set of persons, together with the characteristics of these ties as a whole can be used to interpret the social 
مجلة وادي النيل للاراسات والبحوث الإنسانية والاجتماعية والتربوية (مجلة علمية محكمة)

(ISSN : 2536 - 9555)

behavior of the overall community constituted by these persons.

5. The power of SNA as a distinctive approach lies in its ability to identify Mechanisms of Social Change.

6. SNA has been proven to be useful as well in studying Social Influence ${ }^{2}$ in small as well as large groups (Kleinnijenhuis et. al., 2011).

7. An individual $\mathrm{X}$ is socially influenced by a behavior of another individual $\mathrm{Y}$ in a specific community if and only if $\mathrm{Y}$ is within the network of $\mathrm{X}$, i.e., $\mathrm{X}$ and $\mathrm{Y}$ are linked or tied with any type of relationship (liking, friendship, kinship, marriage, business, trade, etc.).

8. SNA offers an extremely useful tool for studying organized crimes in general, and particularly terror networks. Through mapping and visualization of terror networks using modern personal computers, it is possible now to identify membership links, information flow, money movements, subgroups and key players within terror networks. Hence, it helps in developing strategies for counterterrorism.

9. Network Topology has been proven to be a basic determinant of the diffusion of innovations within organizations or groups in terms of different diffusion parameters e.g., innovation potential, imitation potential, diffusion rate (speed) and adoption size.

10. SNA has also been proven to be very useful in determining opinion leaders in Social Networking Websites such as Facebook and Twitter.

Based on these outcomes, this article proposes a conceptual and analytical framework for using SNA in studying the memetic diffusion of Tolerance.

${ }^{2}$ Social Influence is defined as "a change in a person's cognition, attitude, or behavior, which has its origin in another person or group" (Raven, 1965, p. 371). Social Influence occur "when an actor adapts his behavior, attitude, or belief to the behaviors, attitudes, or beliefs of other actors in the social system" (Leenders, 2002, p. 26). 
A Network Analysis Approach to the Diffusion of Tolerance Memes Amira S. N. Tawadros

مجلة وادي النيل للاراسات والبحوث الإنسانية والاجتماعية والتربوية (مجلة علمية محكمة)

\section{The Diffusion of Tolerance Meme in Social Networks}

Like any idea or concept, tolerance towards "different" others can be represented as a meme that can be transmitted from one person to another through social interactions of any kind, and hence can be diffused within a specific community.

There are many definitions as well as types of tolerance in literature, and it is relative in nature. However, in this study, I am interested in tolerance towards different others in the sense of accepting and allowing the existence of others who are different in gender, race, religion, culture, ethnic group, political view, attitudes, lifestyle, social class, nationality, etc. This conception of tolerance towards different others goes along with Oxford online dictionary (2016) that defined Tolerance as "The ability or willingness to tolerate the existence of opinions or behavior that one dislikes or disagrees with"3.

The main focal questions that this study is concerned with are:

(1) What accounts for the differential diffusion of tolerance memes in different social networks? Put it another way, what are the determinants of the success of tolerance meme in spreading in some networks more than other networks?

(2) What are the micro-structural avenues of tolerance meme diffusion?

(3) What are the structural characteristics of a social network which account for the spread and growth of tolerance meme?

(4) What are the best outreach and engagement channels for diffusing tolerance memes?

3 "Tolerance, n.1". OED Online. March 2016. Oxford University Press. http://www.oed.com/viewdictionaryentry/Entry/11125 (accessed April 17, 2016). 
مجلة وادي النيل للاراسات والبحوث الإنسانية و الاجتماعية والتربوية (مجلة علمية محكمة)

(ISSN : 2536 - 9555)

(5) How could we reach a resilient network of tolerance?

\subsection{Basic concepts in SNA:}

Important structural measures / characteristics of a social network include:

- Network is the unit of analysis in network models. It is defined as a set of interrelated actors. Actors represented as Nodes are linked to each other by one or more than one relational Tie. Nodes may represent individuals, social groups, leaders, companies or any other social entity. Ties represent relationships of any form that can link a pair of actors.

- Cluster is a dense region within a network.

- Network Topology is the arrangement of the various elements (links, nodes) of a social network. Essentially, it is the topological structure of a network that can be visualized, giving valuable insights.

- Network Density (Connectedness) is the proportion of actual ties in the network as a ratio of the total number of possible ties.

- Network Reachability refers to the average number of links (ties) between any two individuals in the network. Networks with high reachability are those with low average Path Length (shortest possible path between two nodes).

- Network Clustering refers to the number of dense regions in the network.

- Network Centrality refers to the degree to which a network is concentrated. High concentration indicates that a small number of people control the flow of resources.

- Actor Centrality refers to the degree to which a specific actor is important or prominent in the network in terms of its location in the network and how it can control or influence flow within this network. Centrality can be measured using many techniques, the most popular three are: Degree Centrality, which refers to the number of ties an actor has to all other actors in the network; Closeness Centrality, which refers 
A Network Analysis Approach to the Diffusion of Tolerance Memes Amira S. N. Tawadros

مجلة وادي النيل للاراسات والبحوث الإنسانية والاجتماعية والتربوية (مجلة علمية محكمة)

to how close an actor is to all other actors in the network. It refers to the number of geodesics (shortest paths) an actor has to all other actors in the network; and Betweenness Centrality, which refers to the number of ties in which an actor lies between two other actors in such a way that any flow of information or resources between these two actors must pass by this actor.

- Star is the individual with the highest number of nominations.

- Bridge (Weak Tie) is an individual who is a member of multiple clusters in the network.

\subsection{The effect of Structural Metrics of a Social Network on Diffusion}

In this section, the effect of some commonly used metrics for the network structure on diffusion of ideas in general is summarized. These metrics include: Network Clustering - Network Density Network Centrality - Network Reachability - Prevalence of Bridges (Weak Ties) - Number of Elites (high Node Centrality) Motivation of Elites (Correlation between Motivation and Position) - Network Resilience.

Based on the outcomes of a huge literature in SNA and its use in analyzing and studying human dynamics, the following notes can be taken into consideration when thinking about general memetic diffusion within social network.

- The higher the Node (Actor) Centrality, the higher the social influence they have on other nodes.

- Highly central actors are more likely to be early adopters of advantageous ideas, while peripheral actors are more likely to adopt risky ideas (Becker, 1970; Burkhardt and Brass, 1990; Rogers, 2003).

- Bridges (Weak Ties) are very important in diffusion process since they connect the unconnected groups or clusters (Granovetter, 1973; Burt, 1992). 
مجلة وادي النيل للاراسات والبحوث الإنسانية والاجتماعية والتربوية (مجلة علمية محكمة)

(ISSN : 2536 - 9555)

- The higher the Network Centrality the faster the diffusion occurs. One adopted by a central actor, a meme will spread rapidly through the network (Valente, 1995).

- The higher the Network (Cluster) Density, the more rapid the diffusion of memes inside this Network (Cluster) (Black, 1966).

- The shorter the average Path Length, the higher the Network Reachability, inside a network, the faster the diffusion occurs (Devaud, 2008).

- The higher the Network Clustering, the more difficult the diffusion of new ideas (memes) become. The more the number of bridges (weak ties) the easier and faster the diffusion occurs.

- The power of Elites is not only conditional on their degree centrality, but also on their common motivation. If they do not share a common motivation towards adopting a specific idea (meme) their power is wasted, since the influence of highlymotivated elites is mitigated by that of low-motivated ones.

- Network Resilience is also a crucial factor for the stability and continuity of any network, and hence in affecting meme diffusion within it as well. Resilience refers to the ability of a network to overcome the removal of central nodes or bridges (which represents a vulnerability to the network formation) through the availability of alternate nodes (actors) to take place of lost central nodes or bridges.

\subsection{The effect of Network Topology}

Some commonly observed structures of real world complex social networks are examined in literature to assess the effect of network topology on different aspect of human dynamics. Six different network topologies are considered, namely: Regular, Small World, Random, Clique, Opinion Leader, and Hierarchical network topologies.

In Regular Networks nodes (actors) are positioned at fixed points in a regular space. Every node is connected to the same number of nodes ( $\mathrm{n}$ nearest neighbors). This topology is characterized by 
A Network Analysis Approach to the Diffusion of Tolerance Memes Amira S. N. Tawadros

مجلة وادي النيل للاراسات والبحوث الإنسانية والاجتماعية والتربوية (مجلة علمية محكمة)

being locally very dense and by having long average paths between nodes.

Random Networks are constructed by placing ties (links) between network nodes randomly, i.e. each pair of nodes has a connecting tie with an independent probability.

Small World Network lies between regular and random networks in the sense of tie randomness. Small world networks are claimed to represent real world systems were ties are very dense locally, but at the same time some ties exist outside the local group (cluster). Small World Networks usually correspond to reasonably dense cities and suburbs. Individuals within this type of social networks have overlapping networks, but each also has some chance to get in contact (tie) with individuals outside his (her) cluster (Watts, 1999; Devaud, 2008; Siegel, 2009).

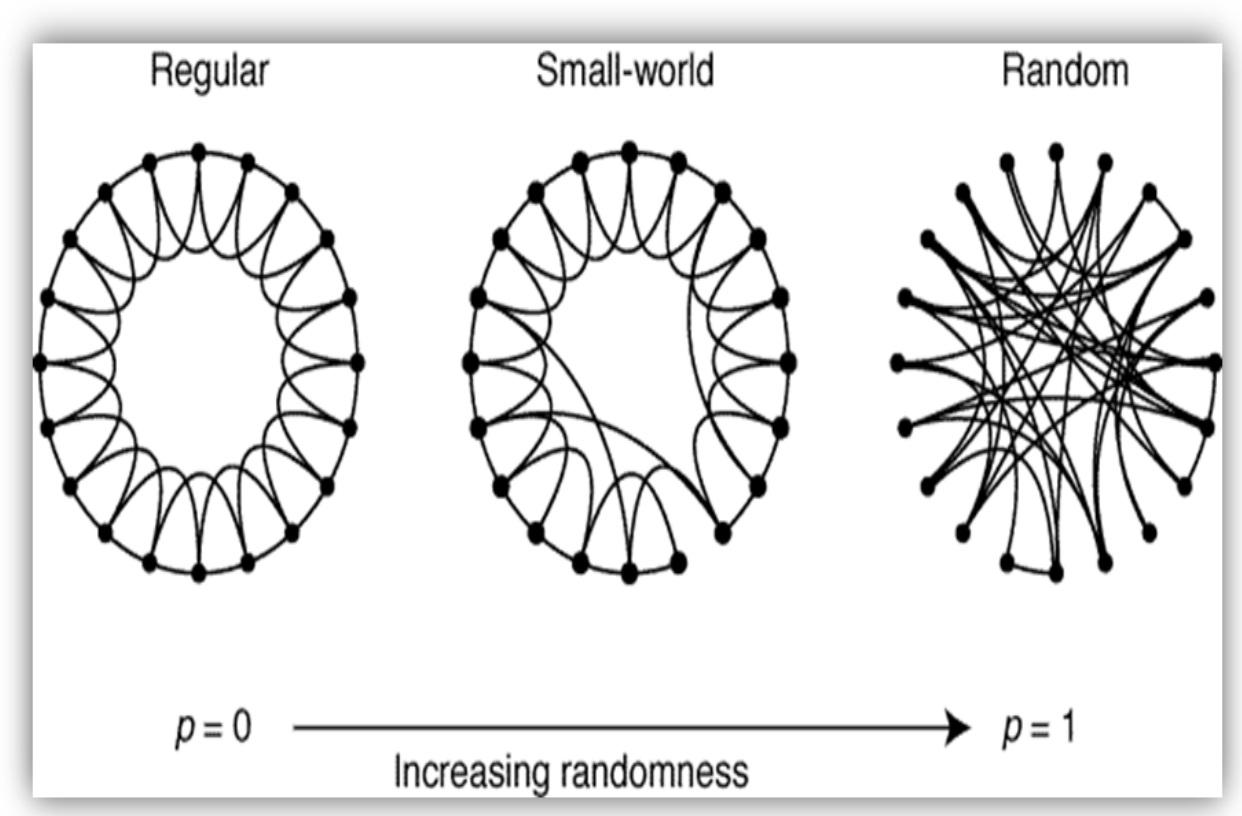

Figure (1): Visualization of Regular, Small World and Random Network Topologies 
مجلة وادي النيل للاراسات والبحوث الإنسانية والاجتماعية والتربوية (مجلة علمية محكمة)

(ISSN : 2536 - 9555)

Clique Network is similar to Small World Network, but are more tightly clustered. Clusters are very dense; Nodes within a specific cluster have ties with almost all other nodes within this cluster. Rare nodes have ties outside their cluster, these nodes are called Bridges. It corresponds to small towns, villages, and cliques, in which everyone is tied to everyone else within the same social unit (cluster), but only rare people who spans multiple cliques acting as social bridges between these cliques.

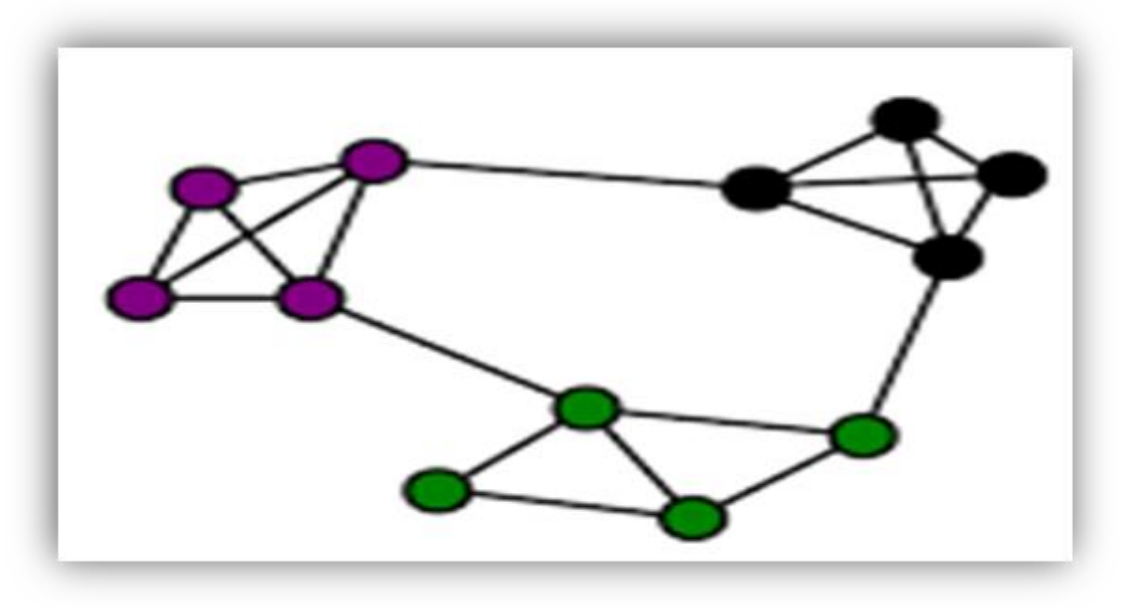

Figure (2): Visualization of Clique Network Topology

In Opinion Leader Network most nodes have few ties to other nodes, while very few nodes have many. These few nodes are considered central in the sense that they have higher Degree Centrality. This network topology corresponds to opinion leaders in regular communities, and due to their large number of connections, once they adopt an idea they affect a large scale of followers in their networks. These are called Stars of the network. 
A Network Analysis Approach to the Diffusion of Tolerance Memes Amira S. N. Tawadros

مجلة وادي النيل للاراسات والبحوث الإنسانية والاجتماعية والتربوية (مجلة علمية محكمة)

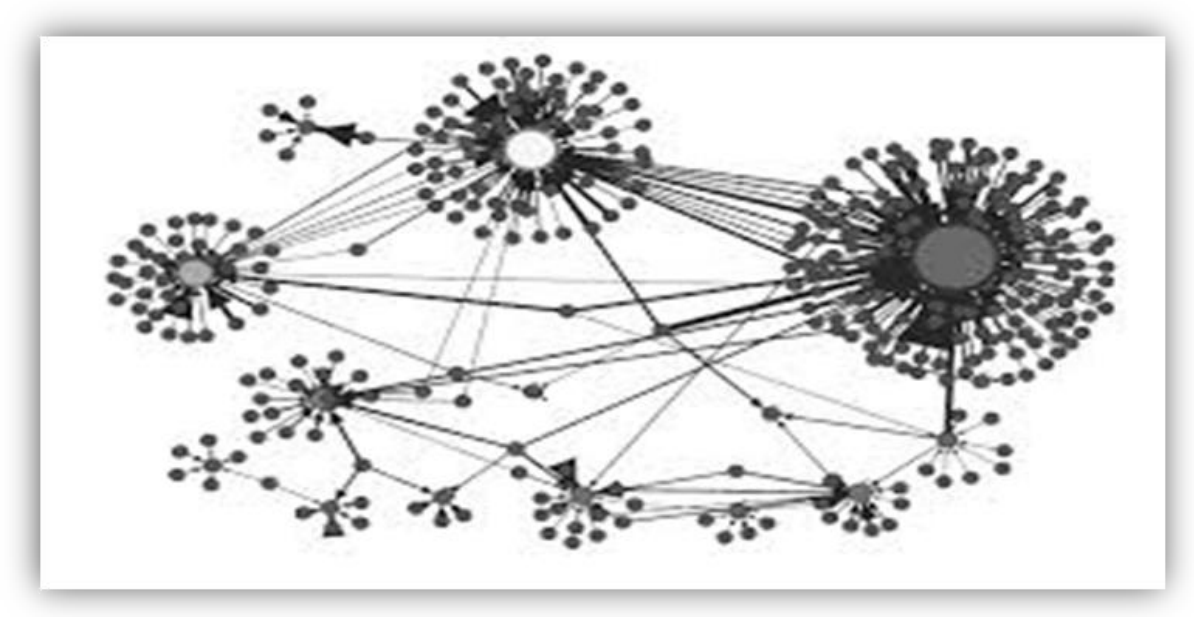

Figure (3): Visualization of Opinion Leader Network Topology

A Hierarchy Network is composed of a series of levels expanding exponentially in width. Each node is tied to one node above and to a number of nodes below it. While the power of Stars or elites in Opinion Leader Networks lies in the greater number of network ties they have, the power of elites in Hierarchy Networks lies in their privileged placement at the top.

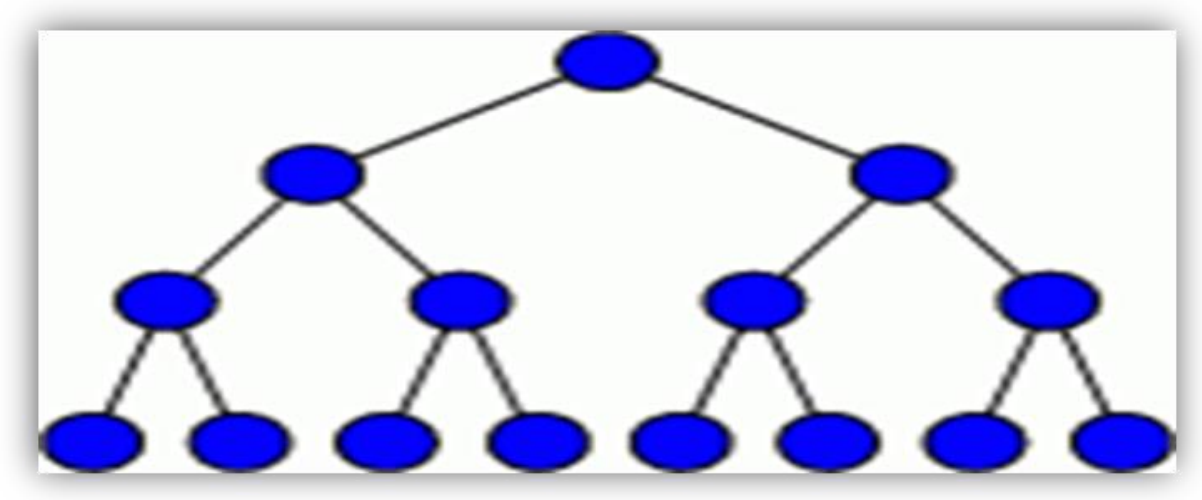

Figure (4): Visualization of Hierarchy Network Topology

This study focuses on Small World, Clique, Opinion Leader and Hierarchy Networks only because these are the forms that simulate real social structures. 
مجلة وادي النيل للاراسات والبحوث الإنسانية و الاجتماعية والتربوية (مجلة علمية محكمة)

(ISSN : 2536 - 9555)

Applying the notes discussed in the previous section to these four different network topologies, we can formulate a complete conceptual framework for memetic diffusion of tolerance in social networks.

\section{A Conceptual Framework for the Diffusion of Tolerance Meme within Social Network}

Building on the discussions in Section (4), regarding the effect of network structural metrics on the diffusion of memes in general, it could be ventured that the diffusion of tolerance meme in particular, or in other words creating a more tolerant network, needs different requirements based on the existing network topology. For this reason the next paragraphs will discuss these requirements for every network topology.

\subsection{Small World Network Scenario}

As previously mentioned, this social network is characterized by very dense local ties and some ties out of the cluster. In these networks, tolerance as a meme is expected to diffuse rapidly given the following conditions are satisfied simultaneously:

- High Cluster Density

- High Network Density

- The existence of a sufficiently large number of Bridges (Weak Ties)

In these networks, since there are no elites having more influence than other nodes, the most appropriate outreach and engagement is through public channels; either face-to-face - leafleting, petitioning, public events, festivals, etc., or mediated - via radio, $\mathrm{TV}$, electronic websites, and newspapers. 
A Network Analysis Approach to the Diffusion of Tolerance Memes Amira S. N. Tawadros

مجلة وادي النيل للاراسات والبحوث الإنسانية والاجتماعية والتربوية (مجلة علمية محكمة)

\subsection{Clique Network Scenario}

Clique networks are perhaps the most difficult type of networks to diffuse tolerance towards different others meme. Generally, this is due to the high network clustering such that any meme can be easily diffused within a specific cluster, but it is very hard to be diffused among clusters. Tolerance meme, particularly, will be more difficult to disseminate within these cultures because of the rare interactions of actors outside their cliques or clusters.

Even with the existence of few bridges between clusters of cliques, this is not sufficient for tolerance meme to propagate or diffuse within the network. In this case, our only way to diffuse tolerance memes is to build more bridges between cliques. This can be done by creating more chance for actors in a given clique to directly interact with another "different" one from another clique.

In these networks, the most appropriate outreach and engagement is through public channels; either face-to-face - leafleting, petitioning, public events, festivals, etc., or mediated - via radio, $\mathrm{TV}$, electronic websites, and newspapers. A good practice here is to invite actors from different cliques to attend public events together. This can, in essence, create new links (bridges) between clustered cliques.

\subsection{Opinion Leader Network Scenario}

Opinion Leader networks have a good potential for the diffusion of tolerance memes because there already exist high central actors, or Stars, who are more influential. However, as previously discussed, if these Stars or Leaders do not share common motivation, their power will be wasted.

In addition, Stars usually become the early adopters of advantageous ideas because they are not going to take the risk their good reputation by applying a destructive idea. This is also a good potential for the diffusion of tolerance meme. 
مجلة وادي النيل للاراسات والبحوث الإنسانية و الاجتماعية والتربوية (مجلة علمية محكمة)

(ISSN : 2536 - 9555)

It could be concluded that, for tolerance memes to propagate in Opinion Leader Networks we need to:

- Identify Central Actors (Stars) in the Social Network.

- Create an advantageous motivation for these Stars through highlighting the importance of tolerance and peace-building for the common benefit of the society.

- Connect Stars (create Ties between them) in order to create a common motivation level. In other words, create a new network of central actors.

- The new network of Central Actors will act as a motivator for all Stars, as well as a factory for creating Backup Stars and hence increase Network Resilience.

In order to create a resilient tolerant network of central actors, the most appropriate outreach and engagement is through private channels with these central actors; either face-to-face - door-todoor leafleting, petitioning, personal recruitment in tolerant movements, etc., or mediated - via telephone or Email.

A good practice here is to invite central actors to participate together in events that raise the common benefit of the society, like charity, dialogue, and conflict resolution projects.

\subsection{Hierarchy Network Scenario}

Hierarchy Networks as well have a good potential since there exists some Elites within the network who are more influential as their positions dictate. However, as long as there is no links or ties between actors in the same level.

It could be concluded that, for tolerance memes to propagate in Hierarchy Networks we need to:

- Create links and Ties between actors in the same organizational level.

- Create personal motivations inside Network Elites, lying in top positions. 
A Network Analysis Approach to the Diffusion of Tolerance Memes Amira S. N. Tawadros

مجلة وادي النيل للاراسات والبحوث الإنسانية والاجتماعية والتربوية (مجلة علمية محكمة)

In order to propagate tolerance meme in hierarchy networks, both public and private channels are needed simultaneously to outreach and engage with the maximum number of actors in the network. Private channels, either face-to-face or mediated, are most appropriate to outreach and engage with Elites, while public channels are most appropriate to outreach and engage with unconnected actors in order to create links and ties between them.

\section{Discussion}

Although there is a massive literature regarding SNA and their applications in social influence and the diffusion of innovations, however this study is distinctive in nature for many reasons.

First, although the concept of toleration and coexistence has been widely studied in literature, together with the factors that foster more tolerance within a particular society. However, this is the first study that sheds the light on structural and relational factors that can either foster or hinder tolerance in a specific society regardless the attributes of individuals constituting this society.

Second, although memetic diffusion has been widely studied in literature, together with the basic criteria for meme propagation and spread. However, this is also the first study to merge SNA and memetic diffusion in a new conceptual and analytical framework.

Third, the study proposes a conceptual framework that can be applied on different types of social networks that lie within different scenarios, and the related venues for the diffusion of tolerance meme under each scenario.

Finally, the study opens the door for future empirical research in the field of tolerance diffusion in different network topologies. 
مجلة وادي النيل للار اسات والبحوث الإنسانية والاجتماعية والتربوية (مجلة علمية محكمة)

(ISSN : 2536 - 9555)

\section{References}

1) Alvarez, A. (2004). Memetics: An Evolutionary Theory of Cultural Transmission. SORITES, 15: $24-28$ [Available online at: http://www.ifs.csic.es/sorites/Issue_15/alvarez.htm].

2) Anderson, R.M., May, R.M. (1991). Infectious Diseases of Humans: Dynamics and Control. Clarendon Press, Oxford.

3) Bailey, N.T.J. (1975). The Mathematical Theory of Infectious Diseases and its Applications. Griffin, London.

4) Becker, H.S. (1970). "Sociological Work: Method and Substance". Aldine, Chicago.

5) Block, A. (1994). East Side-West Side: Organizing crime in New York City [1930-1950]. Transaction, New Jersey.

6) Bruinsma, G. \& Bernasco, W. (2004). Criminal groups and transnational illegal markets. Crime, Law and Social Change, 41: 79-94.

7) Burkhardt, M.E. and Brass, D. J. (1990). Changing Patterns or Patterns of Change: The Effects of a Change in Technology on Social Network Structure and Power. Administrative Science Quarterly, 35(1):104-127

8) Burt, R.S. (1987). Social contagion and innovation: cohesion versus structural equivalence. American Journal of Sociology, 92: 1287-335.

9) Butt, R.S. (1992). Structural Holes. Harvard University Press, Cambridge.

10) Carley, K.M., Lee, J.S., Krackhardt, D. (2002). Destabilizing Networks.

11) Connections, 24 (14). 
A Network Analysis Approach to the Diffusion of Tolerance Memes Amira S. N. Tawadros

مجلة وادي النيل للاراسات والبحوث الإنسانية والاجتماعية والتربوية (مجلة علمية محكمة)

12) Chielens, K., Heylighen, F. (2005). Operationalization of Meme Selection Criteria: Methodologies to Empirically Test Memetic Predictions. In: Proceedings of the Joint Symposium on Socially Inspired Computing (AISB'05). p. [14-20].

13) Coleman, J.S., Katz, E., Menzel, H. (1966). Medical Innovation: A Diffusion Study. Bobbs Merrill, New York.

14) Cross, R., Borgatti, S.P., Parker., A. (2002). Making Invisible Work Visible: Using Social Network Analysis to Support Strategic Collaboration. California Management Review 44(2):25-46

15) Dawkins, R. (1989). The Selfish Gene. Oxford University Press, New York.

16) Devaud, L. (2008). Influence of social networks on spatial diffusion if innovation. Master Thesis. Department of political economy, faculty of Economics and Social Sciences, Friburgensis University.

17) Freeman, L. (2004). The development of social network analysis. A Study in the Sociology of Science.

18) Granovetter, M. (1973). The strength of weak ties. American Journal of Sociology, 78:1360-1380.

19) Granovetter, M. (1978). Threshold Models of Collective Behavior. American Journal of Sociology, 83(5):1420-1443

20) Hales, D. (1996). Modeling Meta-Memes. In: R. Conte and R. Hegselmann (Eds.), Simulating Social Phenomena - LNEMS 456, Springer, Berlin.

21) Heber, A. (2009). The networks of drug offenders. Trends in Organized Crime, 12:1-20. 
مجلة وادي النيل للاراسات والبحوث الإنسانية والاجتماعية والتربوية (مجلة علمية محكمة)

(ISSN : 2536 - 9555)

22) Henson, H. K. (1990). Memes, Meta-Memes and Politics. Singularity, 3.

23) Heylighen F. (1992). 'Selfish' Memes and the Evolution of Cooperation. Journal of Ideas, 2(4):77 - 84.

24) Heylighen, F. (1997). Objective, Subjective, and Intersubjective selectors of knowledge. Evolution and Cognition, 3(1):63 - 67.

25) Heylighen, F. (1998). What makes a meme successful? Selection Criteria for Cultural Evolution. In: Proceedings of the 16th International Congress on Cybernetics, pp. [418-423].

26) Heylighen, F., Chielens, K. (2008). Cultural Evolution and Memetics. In: B. Meyers (ed.), Encyclopedia of Complexity and System Science, Springer, 2008.

27) Katz, D., Kahn, R.L. (1966). The social psychology of organizations. Wiley, New York.

28) Kleemans, E.R., De-Poot, C.J. (2008). Criminal Careers in Organized Crime and Social Opportunity Structure. European Journal of Criminology, 5:69-98.

29) Kleinnijenhuis, J., Hooff, B., Utz, S., Vermeulen, I., Huysman, M. (2011). Social Influence in Networks of Practice: An Analysis of Organizational Communication Content. Communication Research, 38(5):587-612

30) Lauchs, M., Keast, R.L, Le, V. (2012). Social Network Analysis of Terrorist Networks: Can it add value? Pakistan Journal of Criminology, 3(3):21-32

31) Leenders, R. (2002). Modeling Social Influence through Network Autocorrelation: Constructing the Weight Matrix. Social Networks, 24:21-47 
A Network Analysis Approach to the Diffusion of Tolerance Memes Amira S. N. Tawadros

مجلة وادي النيل للاراسات والبحوث الإنسانية والاجتماعية والتربوية (مجلة علمية محكمة)

32) Liu, B.S., Madhavan, R., Sudharshan, D. (2005). DiffuNet: The impact of network structure on diffusion of innovation. European Journal of Innovation Management, 8(2):240-262

33) McIllwain, J.S. (1999). Organized crime: A social network approach. Crime, Law and Social Change, 32:301-323

34) Mitchell, J.C. (1969). Social Networks in Urban Situations. Manchester University Press, Manchester.

35) Moreno, J.L. and Jennings, H.H. (1938). Statistics of social configurations. Sociometry, 1:342-374

36) Morris, S. (2000). Contagion. Review of Economic Studies, 67:57-78

37) Rapoport, A. (1953). Operational Philosophy: Integrating Knowledge and Action. Harper \& Bros., New York.

38) Raven, B. H. (1965). Social Influence and Power. In I.D. Steiner \& M. Fishbein (Eds.), Current studies in social psychology, pp. 371-382. New York: Holt, Rinehart, Winston.

39) Rice, W.E., Yoshioka-Maxwell, A. (2015). Social Network Analysis as a Toolkit for the Science of Social. Journal of the Society for Social Work and Research, 6(3):369-383

40) Rogers, E.M., Kincaid, D.L. (1981). Communication Networks: Toward a New Paradigm for Research. Free Press, New York, NY.

41) Scott, J. (1991). Social Network Analysis: A Handbook. Sage Publications, London, UK.

42) Siegel, D.A. (2009). Social Networks and Collective Action. American Journal of Political Science, 53(1):122-138 
مجلة وادي النيل للار اسات والبحوث الإنسانية والاجتماعية والتربوية (مجلة علمية محكمة)

(ISSN : 2536 - 9555)

43) Snow, D.A., Zurcher, L.A., Ekland-Olson, S. (1980). Social Networks and Social Movements: A Microstructural Approach to Differential Recruitment. American Sociological Review 45(5): $787-801$

44) SUTHERLAND, E. (1937). The Professional Thief by a Professional Thief. University of Chicago Press, Chicago.

45) Tawadros, A.S.N. (2012). Cultures Co-evolution and the Emergence of Cooperation: A Computational Approach. $\mathrm{PhD}$ Thesis, Socio-Computing Department, Faculty of Economics and Political Science, Cairo University, Egypt.

46) Thompson, J.D. (1967). Organizations in Action: Social Science Bases of Administrative Theory. Mc-Graw Hill, New York.

47) Tichy, N.M., Tushman, M.L., Fombrun, C. (1979). Social Network Analysis for Organizations. The Academy of Management Review, 4(4):509-517

48) Valente, T.W. (1995). Network Models of the Diffusion of Innovations. Hampton Press, Cresskill, New Jersey.

49) Wasserman, S. and K. Faust. (1994). Social Network Analysis: Methods and Applications. Cambridge University Press, UK.

50) Weng, L. (2014). Information Diffusion in online Social Networks. PhD Thesis, Center for Complex Networks and Systems Research, School of Informatics and Computing, Indiana University. 